\title{
Disaggregation of Bacterial Cell Walls by Anionic Detergents
}

\author{
By F. SHAFA* AND M. R. J. SALTON \\ Department of Bacteriology, University of Manchester
}

(Received 6 February 1960)

\begin{abstract}
SUMMARY
Isolated cell walls of six Gram-negative bacteria were disaggregated by sodium dodecyl sulphate at all $\mathrm{pH}$ values between $\mathrm{pH} 2$ and 9. Disaggregation as measured by decrease in turbidity showed maxima at pH 3 and 8 . Salmonella gallinarum walls were disaggregated by alcohol sulphate compounds with alkyl chain lengths of $10,12,14$ and 16 carbon atoms; maximum activity was observed with the $\mathrm{C}_{14}$ homologue. No sulphydryl groups were detected on disaggregation of the walls of $S$. gallinarum and $p$-chloromercuribenzoate had no protective action. Autolytic enzymes of Vibrio metchnikovii do not contribute to the dissolution of the walls of this organism by sodium dodecyl sulphate.
\end{abstract}

\section{INTRODUCTION}

The powerful haemolytic properties of sodium dodecyl sulphate (SDS) have long been known, and the mechanism of lysis has been explained in terms of the 'collapse' of oriented lipid and cholesterol layers in the red cell membrane (Schulman, Pethica, Few \& Salton, 1955). Although Gram-negative bacteria are generally resistant to the bactericidal action of certain classes of surface-active anionic compounds (Baker, Harrison \& Miller, 1941 $a$ ), there have been reports of killing by high concentrations (0.2\%) of SDS (e.g. Lominski \& Lendrum, 1942). As the walls of Gramnegative bacteria contain appreciable amounts of lipid (Salton, 1953), it appeared likely that a direct physico-chemical disaggregation of the wall structure may occur on exposure to such surface active compounds as SDS. Salton (1957) reported the complete disaggregation of the isolated walls of several Gram-negative bacteria by SDS. This action on the surface structure of Escherichia coli was confirmed by Bolle \& Kellenberger (1958).

\section{METHODS}

Preparation of cell walls. The cell walls of Escherichia coli, Pasteurella pseudotuberculosis, Proteus vulgaris, Pseudomonas aeruginosa, Salmonella gallinarum and Vibrio metchnikovii were prepared as previously described (Salton \& Horne, 1951), using cells harvested from nutrient agar or nutrient broth in the stationary phase of growth. All cell-wall preparations were treated with trypsin (1 mg./ml., pH 8, $2 \mathrm{hr}$. at $\left.37^{\circ}\right)$, washed thoroughly and stored as thick suspensions in distilled water at $4^{\circ}$.

Disaggregation and turbidity decrease. For comparative purposes, the course and extent of 'disaggregation' of the walls by anionic surface-active compounds was

* Present address: Department of Bacteriology, Faculty of Medicine, University of Tehran, Iran. 
followed by measuring the change in scattering of the cells walls at a wavelength of $700 \mathrm{~m} \mu$ in a Unicam spectrophotometer (Model SP 600). That the turbidity decrease represented a disaggregation of the wall structure was strongly supported by the observation of small particles (c. $100 \AA$. diam.) in the electron microscope, and no residual thinner cell-wall substructure, under conditions of c. $95 \%$ turbidity decrease. The $\%$ turbidity decrease was determined from

$$
\left(\frac{\text { OD initial - OD final }}{\text { OD final }}\right) \times 100 \text {, }
$$

where $\mathrm{OD}=$ optical density measured as above.

The influence of $\mathrm{pH}$ value (buffers of constant ionic strength, $\mu=0 \cdot 1$, described by Miller \& Golder, 1950), temperature and alkyl chain length was investigated by following the course and extent of disaggregation by measurement of the changes in turbidity of cell-wall suspensions.

\section{RESULTS}

\section{Influence of concentration of detergent, $\mathrm{pH}$ value and temperature on the disaggregation of walls by sodium dodecyl sulphate}

The course of dissolution of walls of Salmonella gallinarum by various concentrations of SDS in buffer at pH 3 is shown in Fig. 1. The effect of concentration on the disaggregation of $S$. gallinarum walls as indicated by change in $\%$ turbidity was studied at pH 3,7 and 8. The results are summarized in Fig. 2. The dissolution of the walls of various Gram-negative bacteria by $0 \cdot 2 \%(w / v)$ SDS was studied at various $\mathrm{pH}$ values. The results are compared with those for Salmonella gallinarum in Table 1. The influence of temperature on the disaggregation of the walls by SDS was investigated at three temperatures, namely $18^{\circ}, 3^{\circ}$ and $53^{\circ}$; the results are presented in Table 2.

Table 1. Dissolution of the ralls of some Gram-negative bacteria by sodium dodecyl sulphate

The suspensions of cell walls were adjusted to various $\mathrm{pH}$ values; the SDS concentration was $0.2 \%(w / v)$; incubation at $37^{\circ}$ for $30 \mathrm{~min}$.

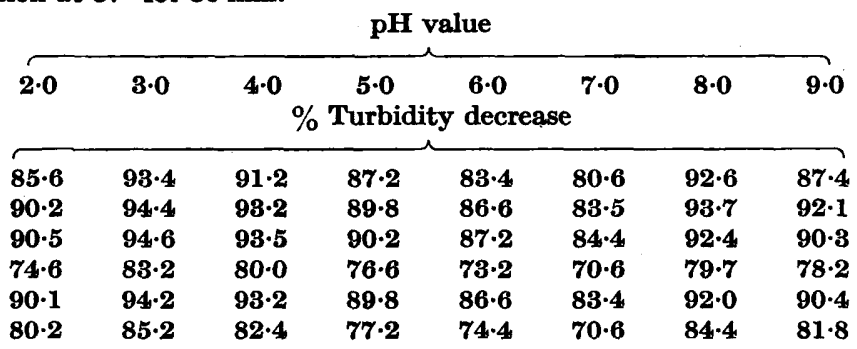

\section{The relationship of the alkyl chain length of anionic surface-active alcohol} sulphates to their lytic activity

Concentrations of sodium decyl sulphate $\left(\mathrm{C}_{10}\right)$, sodium dodecyl sulphate $\left(\mathrm{C}_{12}\right)$, sodium tetradecyl sulphate $\left(\mathrm{C}_{14}\right)$ and sodium hexadecyl sulphate $\left(\mathrm{C}_{16}\right)$ ranging from 0.006 to $0.8 \%(\mathrm{w} / \mathrm{v})$ were tested on the isolated walls of Salmonella gallinarum at pH 7 and $37^{\circ}$; the changes in turbidity are plotted in Fig. 3. 
Table 2. The effect of temperature on the dissolution of some Gram-negative walls

Suspensions at pH 3 ; SDS at $0.2 \%(w / v)$; incubated at $37^{\circ}$ for $30 \mathrm{~min}$.

\begin{tabular}{|c|c|c|}
\hline \multicolumn{3}{|c|}{ Temperature } \\
\hline $18^{\circ}$ & $\mathbf{3} 7^{\circ}$ & $\mathbf{5 3}^{\circ}$ \\
\hline \multicolumn{3}{|c|}{$\%$ Turbidity decrease } \\
\hline $82 \cdot 5 *$ & $93 \cdot 4$ & $\mathbf{9 5 \cdot 5}$ \\
\hline $85 \cdot 1$ & $94 \cdot 4$ & 96.8 \\
\hline $87 \cdot 5$ & $94 \cdot 6$ & $97 \cdot 1$ \\
\hline $70 \cdot 7$ & $\mathbf{8 3 \cdot 2}$ & 83.7 \\
\hline $84 \cdot 1$ & $94 \cdot 2$ & $95 \cdot 1$ \\
\hline 78.4 & $85 \cdot 2$ & $86 \cdot 2$ \\
\hline
\end{tabular}

* The values presented in Table 2 represent the changes in turbidity after adjustment for any changes in the control (i.e. no SDS) cell-wall suspensions incubated at the different temperatures.

\section{Effects of various treatments of the walls on subsequent lytic action of sodium dodecyl sulphate}

Phospholipids have been shown to protect bacteria from the germicidal action of cationic and anionic detergents (Baker, Harrison \& Miller, 1941 b). The effect of lecithin on the dissolution of Salmonella gallinarum walls by SDS was investigated by dividing a wall suspension to which lecithin had been added into two samples, one sample was washed several times with the buffer and resuspended in buffer, the other sample being untreated. SDS was then added to both suspensions and the $\%$ turbidity decrease determined. The lecithin-treated suspension showed a turbidity decrease of $58 \%$ as compared with an $80 \%$ decrease for both the control (no exposure to lecithin) and the lecithin-treated and washed preparation. The results

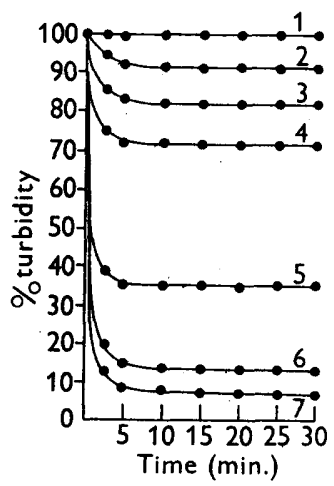

Fig. 1

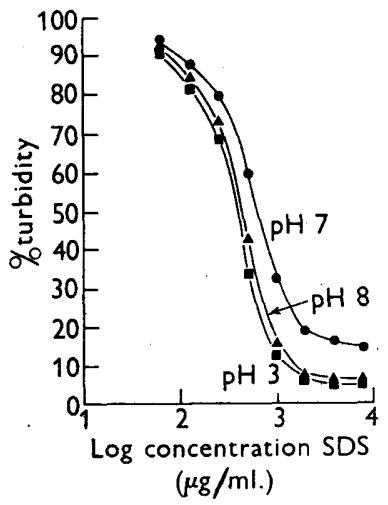

Fig. 2

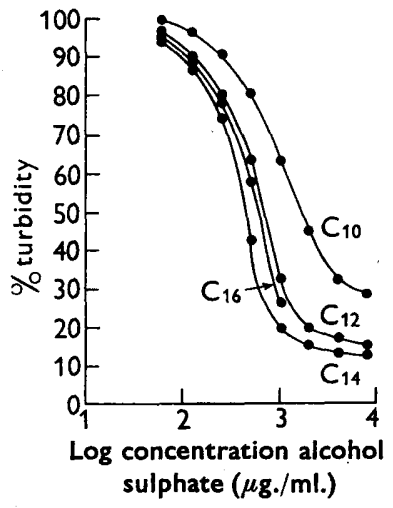

Fig. 3

Fig. 1. Disaggregation of the walls of Salmonella gallinarum measured by changes in turbidity at pH $3 ; 37^{\circ}$. Sodium dodecyl sulphate added to give final concentrations of : $0.006 \%$ (curve 2); $0.012 \%$ (curve 8); $0.025 \%$ (curve 4); $0.05 \%$ (curve 5); $0.1 \%$ (curve 6) and $0.2 \%$ (curve 7 ); untreated walls curve 1 .

Fig. 2. Dissolution of Salmonella gallinarum walls by SDS at $\mathrm{pH} 3,7$ and $8 ; 37^{\circ}$.

Fig. 3. The influence of chain length of alcohol sulphates on the dissolution of walls of Salmonella gallinarum at pH $7 ; 37^{\circ}$. 
suggest that under these conditions the 'protective' effect of lecithin was due merely to its admixture in the wall suspension rather than to strong adsorption on the wall surface and protection of vulnerable groups. If the lecithin is adsorbed, it is evident that it can be readily washed from the wall surface.

Sulphydryl groups are liberated from proteins on treatment with surface active agents (Anson, 1939), and it seemed conceivable that the disaggregating action of SDS might be due either to protein denaturation or to disruption of lipoprotein complexes in the wall. No liberation of sulphydryl groups was detected in the SDStreated wall suspensions of Salmonella gallinarum under conditions which gave a detectable liberation of sulphydryl groups from bovine serum albumin, as tested by the methods of Anson (1939). These results make it appear unlikely that the disaggregation of the walls by long-chain alcohol sulphates, such as SDS, is due to denaturation of protein by disruption of -S-S- bonds. This conclusion is further strengthened by the lack of protective action of $p$-chloromercuribenzoate (concentrations 1-10 $\mu \mathrm{g} . / \mathrm{ml}$.) on the disaggregation of the walls of $S$. gallinarum by SDS.

It may be argued that autolytic enzymes contribute to the lysis or dissolution of the walls. That this is extremely unlikely is supported by experiments with walls of the organism Vibrio metchnikovii which we know to possess an active 'autolysin' which releases the mucopeptide part of the wall (Salton \& Shafa, 1958). No differences in the \% turbidity decrease brought about by SDS were observed as between untreated walls, walls heated for $10 \mathrm{~min}$. at $100^{\circ}$, walls treated with $10 \%$ $(\mathrm{v} / \mathrm{v})$ formaldehyde for $3 \mathrm{hr}$. at $37^{\circ}$, and heated walls treated with an autolysate from $V$. metchnikovii.

\section{DISCUSSION}

In accord with earlier observations (Salton, 1957) the results of this study show that bacterial cell walls are completely disaggregated by anionic surface-active compounds such as SDS, providing the appropriate ratio of compound to wall is used. Our observations suggest that the mechanism of disaggregation of the isolated walls of Salmonella gallinarum (and probably other Gram-negative organisms) involves an interaction between sodium dodecyl sulphate and the lipid, lipoprotein and lipopolysaccharide part of the wall, rather than an action involving rupture of - S-S- bonds. Treatments of the walls of $S$. gallinarum does not appear to 'deterge' or remove the lipoprotein complex from the wall, leaving a residual layer of mucocomplex or mucopeptide. The complete disaggregation was contrary to what we anticipated and the results of our experiments, at least in this respect, differ from what is implied from the work of Bolle \& Kellenberger (1958). Our investigations suggest that the muco-complex part of the wall does not form a continuous, separate layer of the wall, but rather a reinforcing network extending across a multilayered wall (as shown in the thin sections of Escherichia coli by Kellenberger \& Ryter, 1958).

Although anionic compounds such as SDS possess the capacity for direct disaggregation of the isolated cell walls of certain Gram-negative bacteria, the reports of inhibition of lysis by active metabolism (Bolle \& Kellenberger, 1958; discussed by Newton, 1958) point to a more complicated mode of action against intact cells. If the effects can be duplicated, then it would appear that the actively metabolizing cell can exclude a compound such as SDS from its site of action on the cell wall. 
It is of some interest to note the 'double maxima' effects of $\mathrm{pH}$ value on the disaggregation of the isolated walls. Such results are reminiscent of the data obtained for the influence of $\mathrm{pH}$ value on the bactericidal action of cationic compounds on cells of several Gram-negative bacteria (Salton, 1950). The explanation in terms of the cell-wall groups affected is as yet unknown.

One of the aims of the present investigation was to obtain a method for breaking the walls of Gram-negative bacteria into subunits and to obtain some idea of the size of the molecular aggregates and the possible number of different antigenic entities. Considerable difficulty in removing the SDS has been experienced and this method may therefore be unsuitable. However, it is of some interest that the disaggregated wall preparations give several lines of precipitation in agar diffusion plates with cell-wall and intact-cell antisera for Salmonella gallinarum.

We wish to thank Dr D. W. Henderson and Mr F. C. Belton of the Microbiological Research Department, Ministry of Supply, Porton, for a generous supply of Salmonella gallinarum, and Dr A. R. Martin of Imperial Chemical Industries Ltd. (Pharmaceuticals Division), Alderley Park, for a gift of the $C_{10}$ and $C_{14}$ alcohol sulphates.

\section{REFERENCES}

Anson, M. L. (1939). The denaturation of proteins by synthetic detergents and bile salts. J. gen. Physiol. 23, 239.

Baker, Z., Harrison, R. W. \& Mruler, B. F. (1941 a). Action of synthetic detergents on the metabolism of bacteria. J. exp. Med. 73, 249.

Baker, Z., Harrison, R. W. \& Muller, B. F. (1941b). Inhibition by phospholipids of the action of synthetic detergents on bacteria. J. exp. Med. 74, 621 .

Bolue, A. \& Kellenterger, E. (1958). Étude de l'action du laurylsulfate de sodium sur E. coli. Schrweiz. Z. Path. Bakt. 21, 714.

Kellengerger, E. \& RYTer, A. (1958). Cell wall and cytoplasmic membrane of Escherichia coli. J. biophys. biochem. Cytol. 4, 323.

Lominski, I. \& Lendrum, A. C. (1942). The effect of surface-active agents on B. proteus. J. Path. Bact. 54, 421.

Mruner, G. L. \& Golder, R. H. (1950). Buffer of pH 2 to 12 for use in electrophoresis. Arch. Biochem. 29, 420.

Newton, B. A. (1958). Surface-active bactericides. In The Strategy of Chemotherapy. Symp. Soc. gen. Microbiol. 8, 62.

Salton, M. R. J. (1950). The bactericidal properties of certain cationic detergents. Aust. J. sci. Res. 3, 45.

Salton, M. R. J. (1953). The composition of the cell walls of some Gram-positive and Gram-negative bacteria. Biochim. biophys. Acta, 10, 512.

SALTON, M. R. J. (1957). The action of lytic agents on the surface structures of the bacterial cell. Proc. 2nd Int. Congr. on Surface Activity (London), p. 245. London: Butterworth.

Salton, M. R. J. \& Horne, R. W. (1951). Methods of preparation and some properties of cell walls. Biochim. biophys. Acta, 7, 177 .

Salton, M. R. J. \& Shafa, F. (1958). Some changes in the surface structure of Gramnegative bacteria induced by penicillin action. Nature, Lond. 181, 1321.

Schulman, J. H., Pethica, B. A., Few, A. V. \& Salton, M. R. J. (1955). The physical chemistry of haemolysis and bacteriolysis by surface active agents and antibiotics. In Progress in Biophysics. Ed. J. A. V. Butler \& J. T. Randall, pp. 41-71. London: Pergamon Press. 